\title{
THE SIGNIFICANT CONTRIBUTION OF ISLAMIC RELATIONSHIP MARKETING PRACTICE IN MALAYSIAN TAKAFUL INDUSTRY TOWARDS DETERMINING CUSTOMER GRATITUDE, TRUST, AND COMMITMENT
}

\author{
Marhanum Che Mohd Salleh \\ Department of Finance, Kulliyyah of Economics and Management Sciences, \\ International Islamic University Malaysia, 50728 Kuala Lumpur, Malaysia \\ *Corresponding author: marhanum@iium.edu.my
}

Published online: 30 December 2016

To cite this article: Marhanum Che Mohd Salleh. (2016). The significant contribution of Islamic relationship marketing practice in Malaysian Takaful industry towards determining customer gratitude, trust and commitment. Asian Academy of Management Journal, 21(Supp. 1), 171-207. http://dx.doi.org/10.21315/aamj2016.21.supp.1.8

To link to this article: http://dx.doi.org/10.21315/aamj2016.21.supp.1.8

\begin{abstract}
Parallel to the achievement of the Takaful industry, agency system becomes the main medium utilised by the industry to educate the public and assist them about future financial preparation. As a mirror to an Islamic type of insurance, Takaful agents play significant role not only to sell the Takaful products, but also to behave according to the Islamic norms in front of their customers. Thus, this research is conducted to introduce new concept of Islamic relationship marketing (IRM) and investigates its significance towards customer gratitude, trust, and commitment in the industry. A total of 741 of Family Takaful customers in Klang Valley area have participated in the survey conducted in this study. Few statistical analyses were performed to confirm the proposed measures of IRM including descriptive, exploratory factor analysis (EFA), measurement model, and structural equation modelling (SEM) analysis. Through EFA and measurement model, four variables were confirmed to measure the IRM which are Islamic ethical behaviour, social, structural, and financial bonds. Furthermore, these measures of IRM have significantly affected customer gratitude, trust, and commitment via SEM analysis. This study serves as a starting point to promote new approach of marketing in the Takaful industry based on the Islamic norms. It basically aims to tackle the needs of Takaful participants which should be taken care by the Takaful agents as to ensure both of these parties receive benefits in the Takaful contract.
\end{abstract}

Keywords: Islamic relationship marketing, family takaful customer, customer gratitude, customer trust, customer commitment 


\section{INTRODUCTION}

The subject of relationship marketing (RM) has received great attention in Western studies. However, Asian literature addressing this topic remains scarce. Although research in RM is a popular marketing topic and has escalated in the past three decades (Palmatier, Rajiv, Druv, \& Kenneth, 2006), research on this subject from the Islamic perspective is very limited. This subject is interesting from the Islamic perspective because since from the very beginning, Islam has actively defined the types and forms of relationships. The unique nature of Islamic relationships is practiced by means of vertical and horizontal interactions. Through the concept of Tawheed, the vertical interaction of human beings with the creator is emphasised (Yusuf, 2010; Arham, 2010). Meanwhile, the horizontal interaction highlights the interaction among human beings and also with other creations (Yusuf, 2010).

In the context of Islamic Relationship Marketing (IRM), Kartajaya and Sula (2006, p. 27) define Islamic marketing as "a strategic business discipline which directs the process of creation, offering, and exchanging values from one initiator to the stakeholders in which the whole process should be in accordance with the muamalah principles in Islam". Additionally, Islamic marketing, according to Wilson (2012, p. 6) is "an acknowledgement of a God-conscious approach to marketing from a marketer's and/or consumer's perspective which draws from the drivers or traits associated with Islam".

Islamic marketing perceives the marketer as a professional who embodies religious values (Kartajaya \& Sula, 2006), feels accountable to God (Hassan, Chachi, \& Salma, 2008), and is moderate and generous in dealing with customers (Yusuf, 2010; Hassan et al., 2008; Kartajaya \& Sula, 2006; Rice, 1999). Conversely, unethical behaviour such as inequality, injustice, exploitation and cheating are completely impermissible in Islamic marketing (Rice, 1999; Hassan et al., 2008). IRM thus can be interpreted as the marketing process that emerged for the purpose of building relationship between marketer and consumer based on the Islamic guidance towards Allah's (God the Almighty) blessing. There are a number of Qur'anic verses that stress on relationship building. In Surah an-Nisa' verse 1, for example, Allah (God the Almighty) reminds Muslims to forge good relationships among themselves.

O people! Fear your Lord Who created you from a single soul and made its mate from within it, and from that pair spread many men and women and fear Allah in Whose name you ask for (your rights) and pay attention to the ties of relationship. Undoubtedly Allah is watching you all time (Qur'an, an-Nisa': 1) 
As an Islamic alternative for the conventional insurance, the practice of IRM is encouraged in the Takaful industry because it parallel with the Islamic norms which uphold the spirit of brotherhood in the societies. In this context, the study proposes a measurement of Islamic relationship marketing and investigates its importance towards customers' gratitude, trust, and commitment. Overall, it is structured based on the following manner; after the introduction, research problem is discussed and followed by review on the development of Takaful industry and also the importance of relationship marketing (RM) in the industry. Further than that, the paper also discusses on related variables that involve in this study. It is followed by a methodology that was adopted to realise the objectives of the study, data analysis, results, and discussion.

\section{RESEARCH PROBLEM}

Instead of successfully emerged as an alternative insurance product for Muslims in Malaysia, the Takaful industry has failed to instil future commitment of its existing customers, particularly those under the Family Takaful Scheme. Based on information obtained at Bank Negara website, the number of customers who surrendered their Family Takaful Scheme has continued to increase since 2006. Within five years' time; between 2006 and 2010, the highest number was recorded in 2010 in which approximately 139,021 of Family Takaful participants have surrendered their policies (Bank Negara Malaysia, 2010). In addition, in a recent report by Milliman, it was reported that in proportion to total number of policies in Malaysia, 7.4 percent of the participants have surrendered their policies (Ernst \& Young, 2013).

Accordingly, the increase in the number of Family Takaful customers surrendering their policies, has affected the slow rate of Takaful penetration in Malaysia despite the strong support the industry has received from the Malaysian government. Between 2005 and 2010, the Takaful penetration rate has increased by only a small percentage, from 5.7 percent in 2005 to 13 percent in 2012 (Mohd Irwan, 2013). In a study conducted by Mohamed, Syed Othman, and Kamaruddin (2013), it is found that the most influential factors that influenced the low rate of Takaful penetration are distribution channels ( 90 percent of the interviewees agreed), and marketing practices ( 85 percent of the interviewees agreed). Thus, this indicate that study on the distribution channels and its marketing practices has become crucial to influence the penetration rate of Takaful in Malaysia.

In addition, feedback received from six Takaful representatives through informal interviews indicates that there are two main factors that have influenced customers' 
to commit with their policy for long term period which are marketing practices and attitude of Takaful agents. They also reported that the most of the agents are commission-based agents whose goal is to sell Takaful products that offer them high commissions, and in doing so, tend to neglect the needs of their customers. Some agents sell both Takaful and conventional products simultaneously, and some of them tend to promote conventional products by informing their customers that the Islamic products are complex, unattractive, and expensive (Mohamad Shafique, 2013).

To conclude, looking back at the marketing issues in the Takaful industry which have affected the commitment and trust of the customers, it is observed that there is lack of literature in this domain, particularly to uphold the Islamic marketing as a significant tool to be practiced in this industry. Therefore, this research was conducted to address this gap in research by proposing a measure of Islamic relationship marketing, and to examine its influence on customer trust, commitment, and also customer gratitude.

\section{LITERATURE REVIEW}

\section{The Development of Takaful Industry}

Since the introduction of the first Takaful Company in Sudan in 1976, the world has witnessed the growing of the Takaful industry around the world. Among the countries that support the Takaful industry are the GCC country, South East Asian country, Africa, Indian Sub-continent, and Levent country. Malaysia has become the major Takaful player globally with a total net contribution of Family Takaful amounted RM4.5 billion in 2014 (Ernst \& Young, 2014). Additionally, Family Takaful business has shown positive growth than the conventional counterpart in terms of net contributions which was recorded at $12.4 \%$ increase compared to $7.81 \%$ of the net premium of conventional insurance for the period of five years (2009-2014) (Ernst \& Young and MTA, 2015). Globally, the industry has shown a bright future as the amount of Takaful contributions has reached US\$14 billion in 2014 from an estimated US\$12.3 billion in 2013. Year-on-year growth has moderated from a high compound annual growth rate (CAGR) of $22 \%$ (2007-11) to a still healthy growth rate of $14 \%$ over 2012-14. ASEAN countries (Malaysia, Indonesia, Brunei, Singapore and Thailand), driven by strong economic dynamics and young demographics, continue to achieve buoyant growth at 22\% CAGR. The GCC7 countries (excluding Saudi Arabia) registered growth of about $12 \%$.

Accordingly, sharing of global gross Takaful contributions by region in 2014 indicated that Saudi Arabia has majority share nearly half (48\%) of global gross 
takaful contributions. Meanwhile, ASEAN countries, namely Malaysia and Indonesia, accounted for nearly one-third (30\%) of total gross takaful contributions, followed by other GCC countries at 15\%. And Africa, South Asia and Levant accounted for 7\% of global takaful contributions (Ernst \& Young, 2014). These indicate that the global Takaful industry continues to gain market share across several high value rapid-growth markets and this bring to positive vibes in the industry. First, most of the takaful operators are competing intensely which direct to squeeze out the underperformers. Second, performance among the operators are varies significantly. Third, in striving for scale and profitability, operators are looking at structural transformation around risk, pricing and cost efficiencies. However, continuing regulatory reforms have disproportionately increased compliance costs and efforts and significant regulatory divergences across markets has adversely impact the industry's growth and profitability. This represent that the industry still needs strong support from the Islamic banking industry to sustain in the future.

\section{The Importance of Relationship Marketing Practice in Insurance Industry}

In spite of there are mixture of customers, from easy to complicated customers, it is imperative for the service provider, especially the sale agent, to consider relationship marketing (RM) as the ideal marketing approach. This is so by virtue of the objective of RM which is aimed at not just winning the hearts of customers but also considering on how to maintain existing customers. What makes RM so pervasive is that it has been proven to be appropriate to all marketing industries including consumer goods, services and business-to-business settings (Murphy, Lazniak, \& Wood, 2007). It differs from traditional marketing as it does not mean to boost sales, but is an effort to build enduring connections with customers (Takala \& Uusitalo, 1996). Christy, Oliver, \& Penn (1996) assert that successful customer relations are vital as a source of competitive advantage. Moreover, Reichheld \& Kenny (1990) in his book titled 'The Loyalty Effect' claims that customer loyalty will bring profit to the company in the sense that it costs less to serve long-term customers who will help boost sales through referrals to other customers through word of mouth.

While most businesses focus on building good relationships with their customers, not all customers are inclined toward building relationships with business entities. This differs from financial services that offer intangible services and complicated products that require a business intermediary or consultant to explain to customers their products and services. Such a predicament emphasises the responsibility of the sales agents as a consultant. In the Takaful industry, the relationship between agents and their customers is automatically developed because the agent's 
knowledge of the products and services involves interaction and communication between agents and clients which may generate good relationships.

Many researchers studying the financial industry have amply demonstrated how RM significantly generates customer commitment, loyalty, retention, trust, and other positive outcomes. For example, a study in the Malaysian banking industry by Shamsudin, Kassim, Hassan, and Johari (2010) revealed that RM can enhance customer satisfaction and brand loyalty. Maznah and Mohd Noor (2010) also emphasised that RM is not only to attract customers but to ensure maintaining existing customers. Bugel, Buunk, and Verhoef (2010) who studied five different sectors namely the banking industry, health insurance, supermarket, mobile telecom providers and the automotive industry, reveals how improving customer satisfaction and investing in relationships with customers, companies can improve customer commitment and hence customer loyalty.

In addition, Kamsol, Anuar, Norizah, Nik Ramli and Kamaruzaman (2009) stressed that effective RM may produce high affective commitment and customer retention to the company. Most of the above scholars have conducted their studies in the banking industry. All the authors emphasise that it is common for literature in relationship marketing to lead to outcomes pertaining to customer commitment, satisfaction, loyalty, retention and service switching to name a few.

Another study on the Hong Kong banking industry by Adamson, Chan, and Handford (2003) indicates that the adoption of new strategies in relationship marketing and long-term orientation impact on customer commitment and trust. In detail, communications and relational norms were positively correlated with trust and relationship benefits were positively correlated with customer commitment. In this regards, beside the other RM variables, communication is a significant indicator to ensure the success of relationship marketing strategies. The author concluded that banks should develop parallel communication channels with their customers, show flexibility in their dealings and maximise mutual relationship benefits by minimising drastic recovery actions.

A study by Malaysian scholars including Kamsol et al. (2009) who focusing on retaining customers through RM indicates that there is a significant relationship between RM and the four constructs of customer satisfaction, employee commitment, customer trust, and customer loyalty. They revealed that the most significant variable in RM is customer satisfaction. Another recent contribution in RM is by Nath, Gugnani, Goswami, and Gupta, 2009 who presented a systematic view of RM or CRM in three industries namely insurance, banking, and the 
telecommunication industry. The author believes that the importance of RM is to maximise customer satisfaction and enhance overall company profitability.

Two meta-analyses conducted in the context of RM firstly by Swan, Trawick, Jr., Rink, and Robert (1988) followed by Palmatier (2008) are different in terms of their objectives. Swan et al. (1988) focused on the role of trust in relationship development whereas Palmatier (2008) examined the factors that influence the effectiveness of relationship marketing. Based on the study by Swan et al. (1988), trust has successfully develops positive customer attitudes, intentions, and behaviour towards relationship building. Meanwhile, Palmatier (2008) concluded that relationship investment directly affects seller objectives which may explain the impact of RM on performance.

\section{Measure of Islamic Relationship Marketing}

As to compliment the current measure of RM which mostly based on three relational indicators, the current study would contribute to add one more indicator in the aspect of ethicality. In this context, Islam emphasise more towards ethics in all matters of human life, thus it is deemed important to be practiced in the Islamic business like Takaful. The first construct that is proposed to measure the Islamic relationship marketing is Islamic ethical behaviour (IEB). Ethics is described as 'the set of moral principles that distinguish what is right from what is wrong' (Beekun, 2003) (p. 3). Meanwhile, base on (Rizk, 2008), ethics is related to the establishment of general guidance on human action or conduct. Similarly, (Yusuf, 2010) have indicated that ethics is a medium to evaluate human behaviour in terms of goodness or badness by means of a code of ethics. In Islam, the substance of ethics has been accredited in the Qur'an with the term 'khuluq' as in Surah al-QalamVerse4: 'And indeed, you are of a great moral character'.

In this context, Islamic ethics or khuluq is measured in terms of goodness (khair), righteousness (birr), equity (qist), equilibrium and justice ('adl), truth (haqq), established norms (ma'ruf) and piety (taqwa) (Beekun, 2003). In business, ethics is related to how a businessperson allocates resources. Besides, it also exhibits his/her personality. Islam teaches Muslims the proper methods for conducting business (Arham, 2010). It is stated in the Qur'an: 'O you who believe eat not up your property among yourselves unjustly except it be a trade amongst you, by mutual consent. And do not kill yourselves (nor kill one another). Surely, Allah is Most Merciful to you'. (Qur'an, An-Nisaa': 29)

It is clear in the above verse that Allah (God the Almighty) has guided Muslims in doing business and has warned that there is no enforcement in trading and it must 
be practiced fairly and honestly. Business activity has become an essential part in human life as Allah (God the Almighty) commanded Prophet Muhammad (peace be upon him) to be a successful businessman (Arham, 2010). Islam emphasises that business activity should not only be seen as an essential aspect of human life, but also as a foundation for social indulgence (Ali \& Al-Owaihan, 2008).

Accordingly, in the Takaful industry, the responsibility of the Takaful agents is considered as a financial consultant or advisor. In practice, they are responsible to inform and advise the customer about the future financial preparation by proposing a suitable Takaful product based on their needs. This responsibility if executed base on the Islamic ethics, will eventually tight their relationship with the customer. In this regards, the nature of the relationship is much depends on the Takaful agent because he/she is the one that offer the products and provide services to the customer.

Given today's challenging market environment and customer demands for quality services, marketers not only have to be customer-focused but also need to be perceived as Islamic by their customers (Hassan et al., 2008). A review of past literature has revealed a large volume of research in marketing that indicate ethics as among the main issues in marketing and sales (Wotruba, 1990; Piercy \& Lane, 2007). However, only a few of these researches have included religious elements in their domain (Nazlida \& Mizerski, 2010). On that note, Arham (2010) suggests that Islamic teachings could be implemented in the current marketing conjecture. According to Wotruba (1990) and Fu, Richards, Hughes, and Jones (2010), the reason why sales persons need to observe proper ethical behaviour is because it may affect their sales performance. In this context, Fu et al. (2010) have proven that self efficacy and positive attitude have influenced the sales persons' selling intention and this have directly affected their sales performance. They must be sincere in addressing their customers' needs and exert a spirit of brotherhood in dealing with their customers (Nafik, Muhammad \& Ratnasari, 2012).

From another perspective, religious aspect is found to be an important factor in acquiring customers' willingness to deal with the sales person (Nazlida \& Mizerski, 2010). Basically, this relates to religious aspects that promote affiliation, commitment, motivation, knowledge, and social consequences, and is believed to influence customers' confidence with the sales person (Nazlida \& Mizerski, 2010). In addition, Hassan et al. (2008) have advocated that Islamic ethical behaviours play a significant role in the development and maintenance of the buyer-seller relationship. This is further supported by a more recent study by Shamsudin et al. (2010), in which the authors claim that Islamic ethical behaviour has promoted a 
positive environment in relationship marketing practice, and this naturally would lead to customer satisfaction.

Not surprisingly, the two above studies (Hassan et al., 2008; and Shamsudin et al., 2010) discovered similar findings, which is; a sales person's Islamic ethical behaviour (bank advisor) has significantly enhanced customer satisfaction and trust. This finding is supported by Hansen and Riggle (2009) who indicated that, in addition to trust, a sale person's ethical behaviour can also influence customers' commitment. The authors have further emphasised that managers should consider ethics as a unique element in marketing activities; besides other marketing skills, in developing a strong relationship with customers.

The effects of ethical behaviour in marketing practice are also apparent on customer loyalty in addition to customer satisfaction and trust. This is proven in a study on the banking industry by Roman (2003). Similarly, in a study by Huang (2008) on customers' perspective on the banking and insurance industry in Taiwan, it was found that selling behaviour, which gives priority to customers, has a significant positive impact on relationship quality and customer retention. This research thus, hypothesises that;

H1: Takaful agents' Islamic ethical behaviour which measure the IRM will positively affect future customer commitment, trust, and gratitude

\section{Relational Bonds}

The other constructs which is adopted to measure the IRM in this study are social, structural, and financial bonds. As previously explained, these constructs are named as relational bonds and has acknowledged by the previous researchers as major component of relationship marketing (Wilson \& Jantrania, 1993; Wilson, 1995; Cannon \& Perreault, 1999; Arantola, 2002; Alrubaiee \& Al-Nazer, 2010; Anabila, Narteh, \& Tweneboah-Koduah, 2012). These bonds in general, describe the factors that might influence customers to remain with their agent for a long term period. For example, a customer might be happy when the agent frequently keeps in touch with him/her, sent him/her greeting cards in his/her special day, provide after sales services, and other social aspect which represents social bonding between the two parties. Meanwhile, from the perspective of structural and financial bonds, the customer might be interested to receive any services or facilities that make him/her comfortable, and he/she might also be satisfied if he/she receives some economic rewards for participating in the Takaful scheme. 


\section{Social Bonds}

Social bonds are described as 'the degree of mutual personal friendship and liking shared by the buyer and seller' (Wilson, 1995, p. 339). It has a number of dimensions including social interaction, closeness, friendship, and performance satisfaction. In relationship marketing, the basis of this type of bond is from a business-to-business perspective, where it represents strong connections among business organisations (Smith, 1998; Williams, Han, \& Qualls, 1998). Meanwhile, from a customer's point-of-view, social bonding emerges as a result of the benefits received from the relationship with the company (Gwinner, Gremler \& Bitner, 1998; Reynolds \& Beatty, 1999).

Accordingly, social bond is built through interpersonal exchanges that can be measured by the strength of the personal relationship between a buyer and a seller (Rodriguez \& Wilson, 1999; Williams et al., 1998). It also represents a form of non-economic satisfaction for both parties in a relationship with an enduring social exchange (Dwyer, Schurr, \& Oh, 1987). In that regard, Lin, Weng \& Hsieh (2003) have advocated that this type of bond would contain interpersonal interactions that could help maintain customer loyalty. Meanwhile, Berry (1995) and Berry and Parasuraman (1991) described the importance of marketers' interference in building friendships that could help to persuade customers to stay loyal with the company's services. Marketers at this level would want to stay in touch with their customers, and when necessary offer social support to them as well (Berry, 1995).

On another note, Liang and Wang (2005) have stated that a company would show its respect and appreciation to its customers by delivering them gifts as a way to enhance the quality of relationship between them. Hence, it would be necessary for those in the Takaful industry to establish social bonds since the role of Takaful agent goes beyond the selling of Takaful products. This is so because a Takaful agent plays the role of a trustee who is responsible for advising others in the society about their future financial preparations, and along the way instil a spirit of brotherhood among them, especially among the Muslims. Therefore, close interpersonal relationship must exist between the agent and the customer in order to ensure the relationship continues for a long term.

\section{Structural Bonds}

Compare to social bonds, structural bonds are present when a business enhances its relationship with customers by facilitating them to fulfil their needs through a service-delivery system (Lin et al., 2003). Based marketing literature, Wilson 
(1995, p. 339) describes a structural bond as 'a vector of forces that create an impediment to termination of the relationship'. It basically consists of economic, strategic, and technical factors that are developed in relationships that offer benefits to all contractual parties (Rodriguez \& Wilson, 1999, p. 6). In this case, a company might insert some value-added incentives to the product infrastructure that might not available elsewhere to the customer (Berry, 1995).

Service provider may also use structural bonds to maintain customer loyalty (Lin et al., 2003). This is because structural bonds provide an infrastructure that makes a customer feels convenient, and this would give the company a key advantage over its competitors (Sin, Tse, Yau, Lee, \& Chow, 2002). Morgan and Hunt (1994), however, suggested that relationship marketing should only be exercised when it continuously gives advantage to the parties involved; which in this case are the company and the customer. For example, the company provides enough facilities to the customer and as a result, the customer remains loyal with the company. In this instance, both parties enjoy the benefits and may persevere with the relationship for a long-term period.

Interestingly, findings from previous and current studies have indicated that structural bonds may at the end affect customer loyalty and customer retention more than social bonds (Turnbull \& Wilson, 1989; Chiu, Lee, Hsieh \& Chen, 2007). Peng and Wang (2006), however, regard both social and structural bonds as very important in maintaining existing customers. Financial bonds, on the other hand, are preferred when a company needs to attract back customers who have discontinued receiving services from the company. In general, this research perceives structural bonds as of equal importance with other types of bonds that share the goal of enhancing relationship with existing customers in the Takaful industry. Thus, this construct is adopted in the framework of this present research, which at the end contributes towards the objective of measuring Islamic relationship marketing practices in the industry.

\section{Financial Bonds}

The final type of bond is financial bonds. Researchers in the past have argued that one of the motivations for engaging in relational exchanges is to save money (Berry, 1995; Gwinner et al., 1998). In this respect, some researchers agree that this type of bond is at the lowest level of the relationship hierarchy because in business, pricing is the most easily imitated marketing element (Chiu et al., 2007). Hence, service providers may reward loyal customers with special prices (Lin et al., 2003). 
According to Nath and Mukherjee (2012), financial bond is the amount of economic benefit derived in exchange relationship. Business parties will assess the overall cost and choose to reward customers in an effort to maintain relationship instead of choosing other marketing alternatives (Thibaut \& Kelley, 1959). It is a type of retention marketing, where a service provider uses economics benefits such as price, discounts and other financial incentives to secure customers' loyalty (Berry \& Parasuraman, 1991). In a broader sense, Smith (1998) proposes that financial incentives are part of functional bonds in a business-to-business context. He describes functional bonds as 'the multiplicity of economics, performance, or instrumental ties or linkages that serve to promote continuity in a relationship' (p. 79).

Accordingly, in the Takaful industry, financial bonds can be regarded as any economics or material benefits offered to customers by Takaful operators. Examples of such benefit are free gifts for participation, cash payments for hospital admission, promotional packages, end-of-the-year bonuses, and other financial benefits. This present research has investigated whether financial bonds can significantly impact future customer retention in the Takaful industry.

Previous literatures have found that there are positive implications when the marketers (Takaful agents in the context of this study) pay attention towards building strong relational bonds (social, structural, and financial) with their customers. Hsieh, Chiu, and Chiang (2005) suggest that a marketer who demonstrates excellent social and financial bonds would able to retain their customers in the future. Moreover, by extending Ndubishi and Wah (2005)'s earlier research, a recent study on relationship marketing conducted by Anabila et al. (2012) similarly found that social and financial bonds can become important determinants of customer loyalty.

On the other hand, Rodriguez and Wilson (1999), and Lin et al. (2003) have presented that social and structural bonds have become essential factors to enhance trust and commitment in a relationship. Compared to other researchers, Chih, Huang, Yang \& Cho (2009) have included all three types of bonds in their study and arranged them according to their perceived importance starting from social bonds, financial bonds, and finally, structural bonds. They have concluded that relational bonds can influence a customer's trust on the sales person. Their result is supported by the previous study done by Swan et al. (1988).

In this context, Berry and Parasuraman (1991) have stated that financial bond becomes apparent in the financial services industry because it is known as frequency or retention marketing. And since Takaful products promote social elements such as the concept of mutual assistance through donation (social bonds), and also 
require the industry to provide good product facilities to the customers (structural bonds), it is essential to include the three types of bonds in this study.

There are however, limited empirical studies done to investigate the direct effect of relational bonds towards future customer commitment and trust (Lin et al., 2003). It is important to investigate the aspects of relational bonds; which consist of social, structural, and financial bonds, which at the end of the day may reflect the customers' sense of brotherhood, closeness, and feelings that they are part of the company (Sin et al., 2002). However, in a study done in the hotel industry, Shammout, Zeidan, and Polonsky (2006) found that when it comes to customer loyalty, the quality of facilities is a bigger factor than other social and financial services. The situation is quite different with the financial services industry where both the social and structural aspects are just as significant as the financial aspect. In this context, Berry and Parasuraman (1991) have stated that financial bond becomes apparent in the financial services industry because it is known as frequency or retention marketing. And since Takaful products promote social elements such as the concept of mutual assistance through donation (social bonds), and also require the industry to provide good product facilities to the customers (structural bonds), it is essential to include the three types of bonds in this research. Thus, this present research hypotheses that;

H2: Social bonds which measure the IRM will positively affect future customer commitment, trust, and gratitude

H3: Structural bonds which measure the IRM will positively affect future customer commitment, trust, and gratitude

H4: Financial bonds which measure the IRM will positively affect future customer commitment, trust, and gratitude

\section{a) Customer Gratitude}

Customer gratitude is an essential social component of human relations that presents an emotional basis for mutual behaviours (Palmatier, Jarvis, Bechkoff $\&$ Kardes, 2009). Customer gratitude signifies the emotional part of reciprocity and it significant in developing and maintaining successful seller-buyer relational exchanges (Huang, 2015). For years, gratitude has represented an essential component to theories about social relationships and reciprocal behaviors across a multiplicity of disciplines. There are two components of gratitude: affective and behavioural (Palmatier et al., 2009; Hasan, Lings, Neale \& Mortimer, 2014). The affective component refers to feelings of gratitude generated when people "perceive themselves to be the recipient of an intentionally rendered benefit" 
(Emmons 2004, p. 9). Emmons and McCullough (2003) assert that gratitude is a positive emotion that stems from an experience of a positive outcome, intentionally provided by another person, firm or organisation. Feelings of gratitude generate an embedded psychological pressure to return back the assistance received. This basically interpreted through behavioural gratitude such as facial, vocal or gestural indicators of gratitude. According to Harpham (2004), gratitude may be represented by different behaviours. It is an automatic expression of gratitude such as saying "thank you" or "smiles" to the counter parties. In line with Hasan et al. (2014), customer gratitude is considered in this study as an effective response, which arises from the acknowledgment of an advantages received from the Takaful agents.

In this regard, Anderson, Fornell, and Rust (1997), Anderson (1998), Szymanski and Henard (2001), and Brown, Barry, Dacin, and Gunst (2005) have clarified that satisfied customers tend to disperse positive word of mouth, which may reduce the cost of obtaining new customers and increase company profitability. It was also agreed by Dholakia and Morwitz (2002) and Gustafsson, Johnson and Roos, (2005) that developing and maintaining satisfactory customer relationships may reduce customer defection, thus, ensuring long-term relationship with the customers.

\section{b) Customer Trust}

Majority of researchers are relied the trust as believe on promise of exchange party whom the customers has confidence towards the trustworthiness, credibility, benevolence, reliability, and integrity of the sellers. (Schurr \& Ozanne, 1985; Swan \& Trawick, 1987; Crosby, Evans \& Cowles, 1990; Moorman, Deshpande \& Zaltman, 1993; Morgan \& Hunt, 1994; Doney \& Cannon, 1997).

Murphy et al. (2007) on the other hand, regards trust as an ethical element in a relationship because it does not involve any sense of enforcement. It is assumed that trust is of great significance in the relationship value and relationship maintenance stages of the relationship processes proposed by Powers and Reagan (2007). Morgan and Hunt (1994) suggest that trust and commitment may directly impose cooperative behaviours; thus, they help guarantee the success of relationship marketing. In general, this research defines trust as a sense of confidence and reliance on the sales person in terms of his promises, words, and credibility to customers. This definition basically emphasises the definition of trust given by Rotter (1967).

In Islam, trust is important to acknowledge one person's personality that will be respected by others. Prophet Muhammad (peace be upon him) was given the title Al-Ameen which means a person that we can trust. He became a role model 
for Muslims as a businessman who was trustworthy in any circumstances. The study thus looks at this element as an important aspect to enhance the relationship between Takaful agents and their customers. In the context of this research, customer trust is defined as a confidence level of Takaful customers towards their agents based on the service received during the participation. It is parallel with the earlier researchers including Schurr \& Ozanne (1985), Swan \& Nolan (1985), and Swan et al. (1988) who promote trust as the customers' belief and feel that the words or promises made by the marketers can be relied on in the future.

\section{c) Customer Commitment}

There are various definitions of commitment used in literatures in marketing, organisational behaviour, and psychology. In marketing studies, one of the earliest definitions of commitment is given by Dwyer, Schurr, \& Oh (1987), who described it as "an implicit or explicit pledge of relational continuity between exchanges partners" (p. 19). Moorman, Zaltman \& Deshpande, (1992) share a parallel view as they describe commitment as "an enduring desire to maintain a valued relationship" (p. 316). Similarly, Morgan and Hunt (1994) regards commitment as "an exchange partner believing that an ongoing relationship with other is so important as to warrant maximum efforts at maintaining it; that is, the committed party believes the relationship is worth working on to ensure that it endures indefinitely" (p. 23). Other contemporary researchers including Liang and Chen (2009) and Huang (2008) also agree that customer commitment is a willingness of the customer to make efforts at maintaining a relationship with a service provider.

Interestingly, how commitment is viewed and described in marketing research was initially very much influenced by literatures from organisational behaviour and psychology (Jones, Taylor \& Bansal, 2008). This is clearly reflected in the definition given by Jones et al. (2008), who described commitment as "a psychological force that binds an individual to the maintenance of the relationship with a specific target" (p. 474). Moreover, the desire to remain and continue the relationship is influenced by psychological factors like familiarity, friendship, personal confidence, reciprocity, and trust (Fullerton, 2005; Sharma, Young \& Wilkinson, 2006; Menon \& O'Connor, 2007).

\section{METHODOLOGY}

This study is designed quantitatively where the data is gathered through selfadministered questionnaires. Three series of focus group discussions were conducted with academicians and industry players before the final questionnaires 
were finalised and distributed. It was done to ensure the right and proper questionnaire is constructed in the context of the Takaful industry. Based on the feedback and suggestion from focus group members, the final set of questionnaires was distributed to a small sample of Takaful customers as a pilot study. The pilot study was conducted to test the questionnaires and measurement items for clarity and understanding. It is a necessary step in the data collection process to identify any problems with the research instrument, and to determine the content and face validity of the measures used in the questionnaires. In this process, a few marketing and Shariah scholars were involved, as well as 189 Family Takaful customers.

Upon the successful completion the pilot test, the final survey was conducted. The respondents are Family Takaful customers of eleven Takaful operators in various locations in the Klang Valley. Data collected were analysed using two statistical analyses software (Statistical Package for Social Sciences (SPSS) version 19 and Analysis of Moment Structures (AMOS) version 16). Accordingly, the measure of Islamic ethical behaviour are newly built in this research and basically relied on the Qur'anic verses and reviewed by the industry experts during the focus group discussion. On the other hand, the measure of relationship bonds are basically adopted from the past researchers including Crosby et al. (1990), Berry (1995), Lin et al. (2003), and others. Five-point Likert scales is used to measure all the answers given in the survey. Out of 1100, 865 questionnaires were returned; which gives it a response rate of 79 percent. However, due to incomplete answers, 65 questionnaires were rejected at the first screening stage. The remaining 800 questionnaires were brought forward for normality check. In total, after going through all the screening process, 755 questionnaires were selected for final data analysis, which means the actual response rate was 69 percent. For a social science research, this response rate is considered high, and the number in fact exceeded the response rate of 56.7 percent recorded in a previous study on the same domain by Kamsol et al. (2009).

Meanwhile this study specifies the Muslims and non-Muslims Takaful customers who are participating in the Family Takaful scheme in duration more than a year. The choice of Family Takaful is due to its major contribution to the Takaful asset which was 10,536 million compared to the General Takaful plan which was only 1,902 million (Bank Negara Malaysia, 2010). Besides that, it is a long term plan that offers wide coverage to the customers for which after sales services are critically needed. It thus requires a strong relationship between agent and customers as well as a good marketing practice by the Takaful agents. Overall, 714 of Family Takaful customers from 11 Takaful operators have contributed in this study. 


\section{Measures of Islamic Ethical Behaviour}

As discussed previously, marketers' ethical behaviour has an important implication towards the quality of relationship (Wotruba, 1990; Roman \& Ruiz, 2005; Fu, et al., 2010). It enhances positive behaviour of the customers for future transactions. In fact, in the context of this study, the significance of Islamic ethical behaviour is that it helps to determine whether the existing customer will remain with the same operator for long term period. This is because, ethical behaviour will most likely win the confidence of the people (trust), strengthen social bonds, and stimulate the public to focus on achieving their primary responsibility in this world (Ali \& AlOwaihan, 2008). Moreover, Allah (S.W.T) clearly identifies the act of breaking off a relationship as a sin. Allah (S.W.T) says:

Who breaks the covenant of Allah after contracting it and sever that which Allah has ordered to be joined and cause corruption on earth. It is those who are the losers

(Qur'ān, Al-Baqarah: 27)

But those who break the covenant of Allah after contracting it and sever that which Allah has ordered to be joined and spread corruption on earth for them is the curse, and they will have the worst

(Qur'ān, Ar-Ra'd: 25)

Accordingly, all measurement items for Islamic ethical behaviour in this study were developed via two means. The first is based on selected Qur' ānic verses, and the second is achieved through focus group discussions with industry experts and academicians. Overall, the measurements of Islamic ethical behaviour are parallel with the roles of Takaful agent based on the 'wakala' concept. Items on specific aspects of ethical behaviour were inspired by specific verses in the Qur'ān. For example, items on 'responsibility' were based on verse 58 of Sūrah An-Nisaa' and verse 76 of Sūrah Ali-Imran; 'honesty' on verse 8 Sūrah Al-Maidah and verse 3 of Sūrah An-Najm; 'trustworthiness' on verse 10 of Sūrah Al-Fath and verse 76 of Sūrah Ali-Imran; and 'justice' on verse 8 of Sūrah Al-Maidah and verse 8 of Sürah Al-Mumtahanah. There are nine items prepared to measure Islamic ethical behaviour in this research. Table 1 presents details on the measurements of Islamic ethical behaviour in this research. 
Table 1

Measurement Items for IEB

\begin{tabular}{|c|c|c|}
\hline No. & Measurement Items for Islamic Ethical Behaviour & Sources \\
\hline 1 & $\begin{array}{l}\text { My Takaful agent explains clearly about Sharī'ah } \\
\text { aspects of Takaful compared to conventional insurance. }\end{array}$ & $\begin{array}{l}\text { Develop for this research from } \\
\text { focus group discussion }\end{array}$ \\
\hline 2 & $\begin{array}{l}\text { He/she gives me adequate information about Takaful } \\
\text { scheme. }\end{array}$ & $\begin{array}{l}\text { Develop for this research from } \\
\text { focus group discussion }\end{array}$ \\
\hline 3 & $\begin{array}{l}\text { He/she explains to me about the objective of Takaful } \\
\text { which is a donation scheme and mutual cooperation } \\
\text { among the participants. }\end{array}$ & $\begin{array}{l}\text { Develop for this research from } \\
\text { focus group discussion }\end{array}$ \\
\hline 4 & $\begin{array}{l}\text { He/she practices professional attitudes in dewaling } \\
\text { with me. }\end{array}$ & $\begin{array}{l}\text { Develop for this research from } \\
\text { focus group discussion }\end{array}$ \\
\hline 5 & $\mathrm{He} / \mathrm{she}$ is an honest person. & Al-Maidah: 8, An-Najm: 3 \\
\hline 6 & $\mathrm{He} /$ she is a responsible person. & An-Nisaa': 58, Ali-Imran: 76 \\
\hline 7 & $\mathrm{He} /$ she always keeps a good relationship with me. & An-Nisaa': 36 \\
\hline 8 & $\mathrm{He} /$ she protects my confidentiality. & Al-Imran: 173 and An-Nisaa':132. \\
\hline 9 & $\mathrm{He} /$ she wear professional attire while dealing with me. & $\begin{array}{l}\text { Develop for this research from } \\
\text { focus group discussion }\end{array}$ \\
\hline
\end{tabular}

\section{Measures of Relational Bonds (Social, Structural, and Financial Bonds)}

This study measures social bond through the items developed by Berry (1995) and Berry and Parasuraman (1991). These items indicate that a marketer needs to remain connected with customers, build friendships with them, and provide them with indirect support. There are also measurement items adopted from the work of other previous researchers including Crosby et al. (1990), Berry (1995), and Lin et al. (2003). Lin et al.'s (2003) study has confirmed and extensively tested these measurements in a context similar to this research. The remaining two items were developed based on input gathered from focus group discussions.

Meanwhile the measure of structural bond in this study is adopted from the work of Crosby et al. (1990), Berry (1995), Gwinner et al. (1998), Lin et al. (2003), Dibb and Meadows (2001), and Lin et al. (2003), which were adjusted to suit with the context of Takaful customer. Customers are basically asked about the conduct of their Takaful agents regarding personalised Takaful schemes, promptness of response, payment methods, and sources of information on the Takaful products.

The last construct of Islamic relationship marketing incorporated into the research framework is financial bond. This type of relational bond represents the economic benefits received by all parties in a relationship. It can be measured either or both in terms of monetary and non-monetary benefits. Many customers can be motivated 
by monetary benefits when a product provides prospect for money saving (Berry, 1995; Gwinner et al. 1998; Peterson, 1995). In this study, they were asked about the money received at the end of a year in cases where no claims were made, for hospitalisations, and from profit generated from investments in the Takaful fund. Meanwhile, the non-monetary benefits include time saved, gifts received and promotion packages offered to the customer. In particular, this research emphasised that by participating in the Takaful scheme, some customers would receive free gifts and offers on promotional packages by the agent. Thus, their response would be very important to gauge the level of financial bond between them and their agent. Overall, most of the five measurement items developed for this study were based on suggestions by focus group members. Only one of the items was taken from the study by Lin et al. (2003). The item was modified to suit the context of this research. Table 3 presents details on the measurement items.

\section{Measure of Customer Gratitude, Trust and Commitment}

In service industry like Takaful, relational exchange will basically involves interactions between exchange parties (service provider and customer). Interactions will then strengthen value sharing between the parties. In the marketing context, the Takaful agents as service provider invests in the relationship by delivering benefits to the customer (De Wulf, Odekerken-Schroder \& Iacobucci, 2001). These benefits will eventually render to positive emotions in the customer, which in turn increase trust in, satisfaction with and commitment to the seller. The measure of customer gratitude in this study mainly relies on Palmatier et al. (2009)'s study where the authors adapted measures from McCullough, Emmons, and Tsang (2002) like 'I feel grateful to....', I feel thankful to....', and I feel appreciative to......'. This study further adapts these measures to reflect the Takaful industry.

In the context of the current study, customer trust is defined as the confidence level a Takaful customer has towards his/her agent based on the services received during his participation in the Takaful scheme. This is in line with the views of earlier researchers including Schurr and Ozanne (1985), Swan and Nolan (1985), and Swan and Trawick (1987) who explained trust as customers' belief and feelings that the words or promises made by the marketers can be relied on in the future. The measurement instrument on trust developed by Wu and Liu (2007) in the context of the banking sector corresponds with the above definition. The instrument was tested by $\mathrm{Wu}$ and Liu (2007) to study the views of bank customers and it recorded a high value of reliability (Cronbach's alpha of 0.94 ). The instrument is, therefore, adopted into the questionnaire used in this research. The items measuring trust consist of five statements and the respondents are given a five-point rating scale to indicate their degree of agreement towards each of the statement. 
Customer commitment in this research is referred to as continuance commitment. It presents the desire of customers to remain with the relationship, their confidence, and the perceived cost of leaving the marketer or company (Gundlach, Achrol \& Mentzer, 1995; Geyskens, Steenkamp, Scheer \& Kumar, 1996; Moorman, Zaltman \& Deshpande, 1992; Sollner, 1994). All the items in this research are adapted from Meyer and Allen's (1991) three component-scale of organisational commitment. The scale has been used by many previous researchers including Bansal, Irving and Taylor, (2004), and has recorded high value of reliability (0.77) and factor loading (0.777-0.826). However, for the context of this research, participants of focus group discussions have suggested that all the items are rephrased to suit the perspective of Takaful customers. For example, statements like: 'I would face difficulty if my Takaful agent leaves me', was adapted from the original statement: 'It would be very hard for me to leave my organization right now even if I wanted to', which was the original statement used by Meyer and Allen (1991).

\section{DATA ANALYSIS}

As pointed out by Levine (1996, p. 1), 'data analysis is a body of methods that help to describe facts, detect patterns, develop explanations, and test hypothesis'. This study therefore conducts data analysis to describe the marketing phenomena in the Takaful industry. Data analysis in this research involves two stages; first, descriptive analysis and second, structural equation modelling based on AMOS software. The first stage describes the background information of the respondents' understudy whereby the second stage confirms the hypotheses developed in this study using two statistical approaches.

\section{Descriptive Analysis}

The most basic analysis done prior to advance data analysis is descriptive analysis. Basically, it involves identifying the background of the respondents and also examining answers given by respondents on each respective construct. In this regard, this research uses this type of analysis for two purposes. First is to observe background information of the respondents (Family Takaful customers), and second, to examine the perception of the respondents towards the practice of Islamic relationship marketing by their agent.

Based on Table 2, it is observed that the respondents in this study are slightly balance between male (333) and female (381). And this balance could eliminate the response bias in terms of gender. Nevertheless, parallel with an earlier prediction for the context of this research (Takaful industry), majority of them are Muslim 
Table 2

Background of Respondents

\begin{tabular}{|c|c|c|c|}
\hline \multicolumn{2}{|c|}{ Demographic Information } & \multirow{2}{*}{$\frac{\text { Frequency }}{64}$} & \multirow{2}{*}{$\frac{\text { Percent }(\%)}{9.0}$} \\
\hline Takaful Operators & Syarikat Takaful Malaysia Berhad. & & \\
\hline & Etiqa Takaful Berhad. & 83 & 11.6 \\
\hline & Takaful Ikhlas Sdn. Bhd., & 52 & 7.3 \\
\hline & CIMB Aviva Takaful Berhad. & 66 & 9.2 \\
\hline & Prudential BSN Takaful Berhad, & 82 & 11.5 \\
\hline & HSBC Amanah Takaful Sdn. Bhd. & 71 & 9.9 \\
\hline & MAA Takaful Berhad. & 54 & 7.6 \\
\hline & AIA AFG Takaful Bhd. & 68 & 9.5 \\
\hline & AmFamily Takaful Bhd. & 43 & 6.0 \\
\hline & Great Eastern Takaful Sdn. Bhd. & 77 & 10.8 \\
\hline & Hong Leong MSIG Takaful Bhd. & 54 & 7.6 \\
\hline & Total & 714 & 100.0 \\
\hline \multirow[t]{3}{*}{ Gender } & Male & 333 & 46.6 \\
\hline & Female & 381 & 53.4 \\
\hline & Total & 714 & 100.0 \\
\hline \multirow[t]{5}{*}{ Race } & Malay & 612 & 85.7 \\
\hline & Indian & 24 & 3.4 \\
\hline & Chinese & 68 & 9.5 \\
\hline & Others & 10 & 1.4 \\
\hline & Total & 714 & 100.0 \\
\hline \multirow[t]{5}{*}{ Marital Status } & Single & 265 & 37.1 \\
\hline & Married & 430 & 60.2 \\
\hline & Divorced & 16 & 2.2 \\
\hline & Others & 3 & 0.4 \\
\hline & Total & 714 & 100.0 \\
\hline \multirow[t]{6}{*}{ Sector of Occupation } & Government & 88 & 12.3 \\
\hline & Semi-Government & 50 & 7.0 \\
\hline & Private & 474 & 66.4 \\
\hline & Self-employed & 97 & 13.6 \\
\hline & Others & 5 & 0.7 \\
\hline & Total & 714 & 100.0 \\
\hline \multirow[t]{7}{*}{ Education Level } & SPM & 123 & 17.2 \\
\hline & Diploma & 199 & 27.9 \\
\hline & Degree & 320 & 44.8 \\
\hline & Master & 48 & 6.7 \\
\hline & $\mathrm{PhD}$ & 4 & 0.6 \\
\hline & Other & 20 & 2.8 \\
\hline & Total & 714 & 100.0 \\
\hline
\end{tabular}


Malays (86\%). Only small numbers of non-Muslims involved in this research (14\%). In addition, more than half of the respondents are married (60\%) and worked at private company (66\%). Further than that, in terms of education, near half of the respondents are degree holder (45\%) and only small portion of them (4 respondents) are $\mathrm{PhD}$ holders. This has exaggerated high number of respondents who are in the group of income from 2000 to 4000 which basically either a degree holder or have industry experiences.

\section{Exploratory Factor Analysis}

An exploratory factor analysis is conducted to find the underlying dimensions of Islamic relationship marketing from the perspective of Family Takaful customers. Based on past literatures and three series of focus group discussion, 23 statements were developed representing the practice of Islamic relationship marketing in the Takaful industry. All necessary procedures that are required prior to factor analysis were conducted and principal component analysis was utilised as the extraction method. Results indicate that measure of sampling adequacy (Kaiser-MeyerOlkin-KMO) was 0.937 and hence is appropriate for factor analysis using principle component analysis (PCA) method. The Bartlett's Test of Sphericity also reached statistical significance (0.000), supporting the factorability of the correlation matrix. Using Varimax rotation, five factors were extracted with eigenvalues greater than one, explaining 68 percent of total variance. Respectively, all five factors were named as knowledge sharing, customer caring, social, structural, and financial bonds.

Table 3 presents the overall results of EFA and also depicts the communality of each variable (between 0.530 and 0.819 ) which higher value represents higher correlations among the constructs. Since factor 1 (customer caring) has the highest eigenvalue and variance (eigenvalue $=9.75$, variance $=42$ percent), it automatically signifies as the most important factor perceived by the Takaful customers as to measure the Islamic relationship marketing practices in the industry. This is followed by factor 2 (social bonds) (eigenvalue $=2.18$, variance $=9.5$ percent), factor 3 (knowledge sharing) (eigenvalue $=1.49$, variance $=6.5$ percent), factor 4 (structural bonds) (eigenvalue $=1.15$, variance $=5$ percent), and factor 5 (financial bonds) (eigenvalue $=1.08$, variance $=4.7$ percent).

Overall, results of factor analysis has regarded that there were five underlying constructs deemed to be relevant as to measure the Islamic relationship marketing in the Takaful industry. They are customer caring, social bonds, knowledge sharing, structural, and financial bonds. However, based on the Qur' ānic sources and the experts' suggestion, all items of customer caring and knowledge sharing 
Table 3

Results of Exploratory Factor Analysis for IRM

\begin{tabular}{|c|c|c|c|c|c|c|c|}
\hline & Measurements of Contructs & $\begin{array}{l}\text { Customer } \\
\text { Caring }\end{array}$ & $\begin{array}{l}\text { Social } \\
\text { Bonds }\end{array}$ & $\begin{array}{l}\text { Knowledge } \\
\text { Sharing }\end{array}$ & $\begin{array}{l}\text { Structural } \\
\text { Bonds }\end{array}$ & $\begin{array}{l}\text { Financial } \\
\text { Bonds }\end{array}$ & Communality \\
\hline 1. & $\begin{array}{l}\text { My Takaful representative is } \\
\text { an honest person. }\end{array}$ & 0.809 & & & & & 0.735 \\
\hline 2. & $\begin{array}{l}\mathrm{He} / \text { she is a responsible } \\
\text { person. }\end{array}$ & 0.785 & & & & & 0.808 \\
\hline 3. & $\begin{array}{l}\mathrm{He} / \text { she always keeps a good } \\
\text { relationship with me. }\end{array}$ & 0.757 & & & & & 0.726 \\
\hline 4. & $\begin{array}{l}\mathrm{He} / \text { she protects my } \\
\text { confidentiality. }\end{array}$ & 0.750 & & & & & 0.747 \\
\hline 5. & $\begin{array}{l}\text { He/she wear professional } \\
\text { attire while dealing with me. }\end{array}$ & 0.739 & & & & & 0.693 \\
\hline 6. & $\begin{array}{l}\text { My Takaful representative } \\
\text { contacts me to keep in touch. }\end{array}$ & & 0.778 & & & & 0.691 \\
\hline 7. & $\begin{array}{l}\mathrm{He} / \text { she asks my feedback } \\
\text { about his/her services. }\end{array}$ & & 0.755 & & & & 0.717 \\
\hline 8. & $\begin{array}{l}\text { I receive greeting cards or } \\
\text { gifts from him/her on any of } \\
\text { my special occasion. }\end{array}$ & & 0.741 & & & & 0.704 \\
\hline 9. & $\begin{array}{l}\text { He/she would call or meet } \\
\text { me whenever I encounter } \\
\text { any problem. }\end{array}$ & & 0.705 & & & & 0.668 \\
\hline 10. & $\begin{array}{l}\mathrm{He} / \text { she provides services } \\
\text { after I participate in the } \\
\text { Takaful scheme. }\end{array}$ & & 0.703 & & & & 0.633 \\
\hline 11. & $\begin{array}{l}\text { My Takaful representative } \\
\text { explains clearly about } \\
\text { Shariah aspects of Takaful } \\
\text { compared to conventional } \\
\text { insurance. }\end{array}$ & & & 0.803 & & & 0.819 \\
\hline 12. & $\begin{array}{l}\text { He/she gives me adequate } \\
\text { information about Takaful } \\
\text { scheme. }\end{array}$ & & & 0.760 & & & 0.766 \\
\hline 13. & $\begin{array}{l}\mathrm{He} / \text { she explains to me about } \\
\text { the objective of Takaful } \\
\text { which is a donation scheme } \\
\text { and mutual cooperation } \\
\text { among the participants. }\end{array}$ & & & 0.742 & & & 0.714 \\
\hline 14. & $\begin{array}{l}\mathrm{He} / \text { she practices professional } \\
\text { attitudes in dealing with me. }\end{array}$ & & & 0.657 & & & 0.670 \\
\hline 15. & $\begin{array}{l}\text { My Takaful representative } \\
\text { provides personalised } \\
\text { Takaful scheme according to } \\
\text { my needs. }\end{array}$ & & & & 0.758 & & 0.640 \\
\hline
\end{tabular}


Table 3 (Continued)

\begin{tabular}{|c|c|c|c|c|c|c|}
\hline Measurements of Contructs & $\begin{array}{l}\text { Customer } \\
\text { Caring }\end{array}$ & $\begin{array}{l}\text { Social } \\
\text { Bonds }\end{array}$ & $\begin{array}{l}\text { Knowledge } \\
\text { Sharing }\end{array}$ & $\begin{array}{l}\text { Structural } \\
\text { Bonds }\end{array}$ & $\begin{array}{l}\text { Financial } \\
\text { Bonds }\end{array}$ & Communality \\
\hline $\begin{array}{l}\text { 16. I receive a prompt response } \\
\text { whenever I make a } \\
\text { complaint. }\end{array}$ & & & & 0.703 & & 0.702 \\
\hline $\begin{array}{l}\text { 17. The Takaful operator } \\
\text { provides various ways for the } \\
\text { payment of contribution. }\end{array}$ & & & & 0.667 & & 0.706 \\
\hline $\begin{array}{l}\text { 18. I can retrieve any } \\
\text { information about the } \\
\text { company and products from } \\
\text { various sources. }\end{array}$ & & & & 0.595 & & 0.668 \\
\hline $\begin{array}{l}\text { 19. My Takaful representative } \\
\text { gave me free gift when I } \\
\text { first participated in Takaful } \\
\text { scheme. }\end{array}$ & & & & & 0.731 & 0.596 \\
\hline $\begin{array}{l}\text { 20. He/she offers a promotion } \\
\text { package during my } \\
\text { subscription of the scheme. }\end{array}$ & & & & & 0.709 & 0.598 \\
\hline $\begin{array}{l}\text { 21. I will receive a sum of } \\
\text { money at the end of the year } \\
\text { in case I did not make any } \\
\text { claim. }\end{array}$ & & & & & 0.694 & 0.588 \\
\hline $\begin{array}{l}\text { 22. I entitle to receive a sum } \\
\text { of money from Takaful } \\
\text { company in case I admitted } \\
\text { to hospital. }\end{array}$ & & & & & 0.649 & 0.530 \\
\hline $\begin{array}{l}\text { 23. I receive some profit from } \\
\text { my Takaful scheme as it is a } \\
\text { saving/investment account. }\end{array}$ & & & & & 0.538 & 0.536 \\
\hline Eigenvalue & 9.746 & 2.179 & 1.493 & 1.154 & 1.081 & \\
\hline$\%$ of variance & 42.376 & 9.476 & 6.491 & 5.016 & 4.699 & \\
\hline Cumulative \% & 42.376 & 51.851 & 58.342 & 63.359 & 68.057 & \\
\hline
\end{tabular}

basically come from one construct which is Islamic ethical behaviour. Thus, it is defined as second order factor for the construct of Islamic ethical behaviour and was confirmed via measurement model which discussed in the next section. In addition, the other constructs (social, structural, and financial bonds) were known as relational bonds. It is deemed as key components of relationship marketing (Dwyer et al., 1987; Wilson \& Jantrania, 1993; Cannon \& Perreault, 1999 and other related researchers). Strengthening relational bonds and practicing the Islamic values while transacting with customers becomes the main objective of the practice of Islamic relationship marketing promotes in this research. 


\section{Results: Measurement Model of Islamic Relationship Marketing}

Once the four proposed constructs of Islamic relationship marketing (Islamic ethical behaviour, social, structural, and financial bonds) were confirmed with their measurement items, measurement model of Islamic relationship marketing was conducted by combining the four constructs in the measurement model. This procedure was done to confirm the four measurements of the Islamic relationship marketing practices which are Islamic ethical behaviour, social, structural, and financial bonds for the Takaful industry.

Results obtained indicate that the model is fit considering that all of the fit indices achieved the cut off value based on fit indexes stated in Hair, Black, Babin and Anderson (2010) $(\mathrm{df}=100$, chi square $=513.53, \mathrm{GFI}=0.92, \mathrm{CFI}=0.93, \mathrm{IFI}=0.93$, and RMSEA $=0.06)$. In addition, all constructs obtained high loading $(>0.7)$ to measure Islamic relationship marketing (IEB $=0.84$, social bonds $=0.80$, structural bonds $=0.91$, and financial bonds $=0.70$ ). These results indicate that, based on the sample of this research, the four constructs are significantly proven able to measure Islamic relationship marketing in the Takaful industry. The four constructs, therefore, are acceptable measures of Islamic relationship marketing. Figure 1 presents the results of measurement model for Islamic relationship marketing.

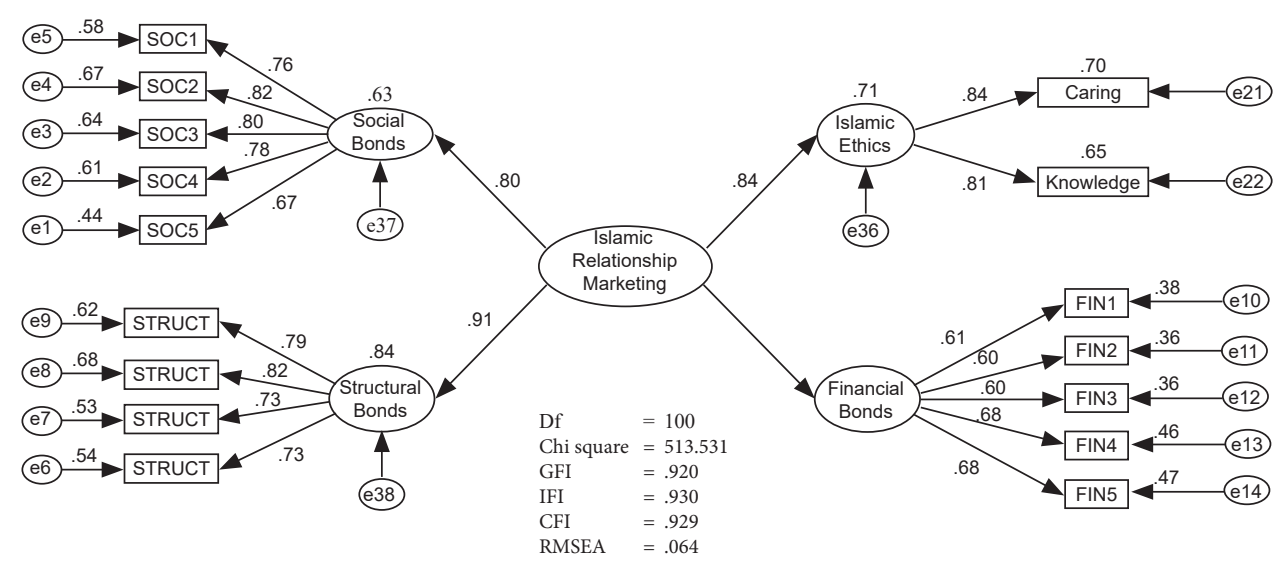

Figure 1. Measurement Model of Islamic Relationship Marketing

\section{Results: The Effect of IRM Towards Customers' Gratitude, Trust and Commitment}

Structural model is developed to test the effect of IRM practice towards customer gratitude, trust and commitment. As illustrates in Figure 2, results of SEM shown that the model have achieved all the fit indices where IFI $=0.967, \mathrm{CFI}=0.967$, 
TLI $=0.961$, and RMSEA $=0.062$ given the $\mathrm{p}$ value $=0.000$, and chi square $(\mathrm{CMIN})=474.72$. Accordingly, all the measures support the model fit assumption, thus the model is proceed to the next level which is the interpreting of the parameter estimated by SEM. Based upon the value of regression weights, it is confirmed that the regression model of Islamic relationship marketing in the customer satisfaction and retention prediction is significantly different from zero at the 0.001 level. In details, when the Islamic relationship marketing goes up by 1 standard deviation, it will influence the increase of customer gratitude, trust, and commitment by 0.90 and 0.79 standard deviations respectively.

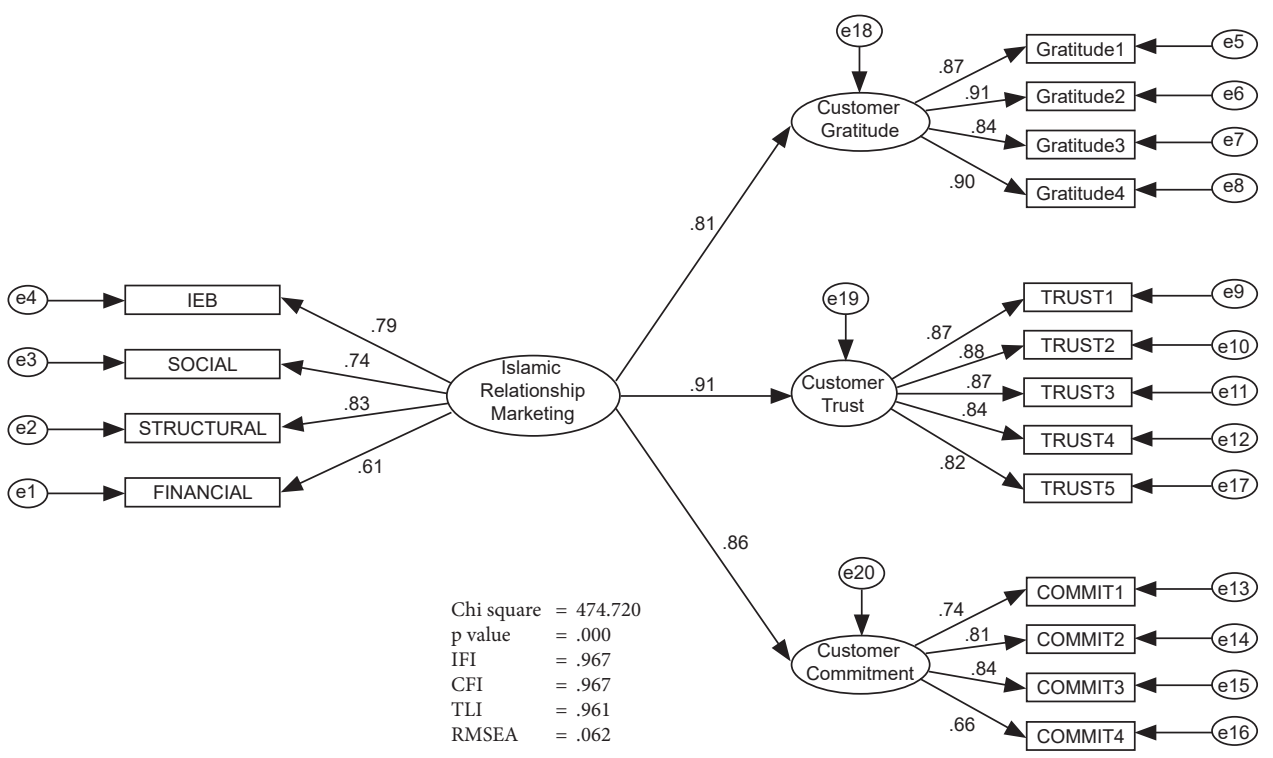

Figure 2. Structural Model

In addition, to scrutiny the effect of IRM towards the three variables in this research, value of squared multiple correlation (R2) have been observed. Based on SEM results, the highest value is belong to customer trust $(0.91)$ which indicate that 91 percent of customer trust is the results of IRM practice. Other than that, IRM also have influenced customer commitment by 86 percent and customer gratitude by 81 percent. This result provides a clear picture to the industry on the significance of the practice relationship marketing in accordance with the Islamic norms. H1, H2, $\mathrm{H} 3$, and $\mathrm{H} 4$ is thus supported by the results of this analysis. 


\section{RESULTS AND DISCUSSION}

Many previous researchers have asserted that relationship marketing practices have great implication towards strengthening buyer-seller relationship (Crosby et al., 1990; Boles, James, Thomas Brashear, Danny Bellenger \& Hiram Barksdale, 2000; Tam \& Wong, 2001; Sin et al., 2002; Huang, 2008; Nath et al., 2009; Bugel et al., 2010; Maznah \& Mohd Noor (2010). In addition, studies on the financial services industry have revealed that relationship marketing have influenced customers to become committed to, and loyal with the same company (Crosby et al., 1990; Reichheld, 1996). This is parallel with the definition of relationship marketing by Hussnain (2011, p. 3), in which relationship marketing is described as "the whole relationship between suppliers and customers" with the objective of giving "the best possible attention, customer services and therefore build customer loyalty".

Among the contributions of this research is to develop the underlying dimensions of the Islamic relationship marketing for the Takaful industry and for this reason, it become the first objective of this research. Few stages were performed to explore the important aspects of relationship marketing suitable with the context of Takaful industry. The first stage was done by reviewing the previous marketing literatures and also related Qur'anic verses in order to come out with measures of Islamic relationship marketing. The second stageltook place when three focus group discussions were held with industry experts, academician, and Takaful secretariat (MTA) to review the measurement items which were developed in the first stage based on the context of Takaful. In this stage, some improvement and enhancement were made to the measurement items and it further proceeded to the next stage which was pilot test.

The results of the pilot test have confirmed the reliability of the measures where all 23 items were remained for the final data analysis. The final stage is done through statistical analysis, or EFA. All 23 measurements items of Islamic relationship marketing were analysed simultaneously and the results indicate that there were five factors or constructs underlined the practice of Islamic relationship marketing as perceived by the Takaful customers. All items basically fell under the specific constructs which initially identified through the literatures and known as customer caring, knowledge sharing, social, structural, and financial bonds. However, two constructs (customer caring and knowledge sharing) were basically proposed as under the same construct which is Islamic ethical behaviour. In this regards, the decision is made to classify these constructs under the Islamic ethical behaviour. As consequent, the four constructs of Islamic relationship marketing together with its measurement items which is proposed in this research were statistically 
significant underlined the practice of Islamic relationship marketing in the Takaful industry. These results were further confirmed by the CFA via measurement model which was performed to reach the research objective number two.

This study also investigates the effect of the Takaful agents' Islamic relationship marketing practice towards customer gratitude, trust, and commitment. Base on SEM-AMOS analyses, it is found that the practice of IRM have significantly influenced the customers' gratitude, trust, and commitment. In other words, it simplifies that the practice of relationship marketing base on the Islamic norms may enhance the quality of relationship between the Takaful agents and customers. In this regards, the Takaful operators must ensure that their agents offer and provide special services with social benefits to the customers as well as provide proper facilities to their customers (Gwinner et al., 1998). Furthermore, as an Islamic alternative to the conventional insurance, the customers suppose to feel more comfortable once they participate to the Takaful scheme since all the prohibited elements are totally intolerable in the industry. The agents in this instance need to cultivate the Islamic ethics while servicing their customers as well as approaching potential customers.

In conclusion, parallel with the previous researchers, this research found that in current competitive market, marketers have to be customer-focused and at the same time need to be perceived as Islamic by their customers (Hassan et al., 2008). The ethical elements have become the prominent element in marketing approach where it may affect the sales performance of the marketers (Wotruba, 1990; Piercy \& Lane, 2007; Nazlida \& Mizerski, 2010; Arham, 2010; Fu et al., 2010). In addition, the marketers (Takaful agents in the context of this research) must sincere in addressing their customers' needs and prepare themselves with enough knowledge on Takaful and the financial sector besides enhancing their marketing skills (Nafik et al., 2012). Furthermore, the three aspects of relational bonds which are social, structural, and financial bonds were deemed important in the practicing the Islamic relationship marketing (Chih et al., 2009). The agents were advised to take care of personal relationship with their customers and at the same time provide their customer with good facilities, efficient services, and enough financial benefits.

Some limitation was emerged in the current study. First, in terms of number of variables, this study only involved four variables of relationship investment, a mediator, and two relationship outcomes (customer trust and commitment). Future researchers may add other significant variables that are appropriate to the context of their research. Future researchers may possibly conduct more advance and relevant analysis to gauge the customers' preference towards Takaful protection scheme. Finally, given limited literatures from the perspective of Takaful agents 
and Islamic marketing, this research advises future researchers to strengthen the elements of Islamic marketing in order to contribute into relationship marketing literatures.

\section{REFERENCES}

Adamson, I., Chan, K.-M., \& Handford, D. (2003). Relationship marketing: Customer commitment and trust as strategy for the smaller Hong Kong corporate banking sector. International Journal of Bank Marketing, 21/6/7, 347-358. http://dx.doi. org/10.1108/02652320310498492

Ali, A. J., \& Al-Owaihan, A. (2008). Islamic work ethics: A critical review. Cross Cultural Management: An Interntional Journal, 15(1), 5-19. http://dx.doi. org/10.1108/13527600810848791

Alrubaiee, L., \& Al-Nazer, N. (2010). Investigate the impact of relationship marketing orientation on customer loyalty: The customer's perspective. International Journal of Marketing Studies, 2(1), 155-174. http://dx.doi.org/10.5539/ijms.v2n1p155

Anabila, P., Narteh, B., \& Tweneboah-Koduah, E. Y. (2012). Relationship marketing practices and customer loyalty: Evidence from the baking industry in Ghana. European Journal of Business and Management, 4(13), 51-61.

Anderson, J. C., \& Narus, J. A. (1984). A model of the distributor's perspective of distributor manufacturer working relationships. Journal of Marketing, 48(Fall 1984), 62-74. http://dx.doi.org/10.2307/1251511

Anderson, E. W., Fornell, C., \& Rust, Roland, T. (1997). Customer satisfaction, productivity, and profitability: Differences between goods and services. Marketing Science, 16(2), 129-145. http://dx.doi.org/10.1287/mksc.16.2.129

Anderson, E. W. (1998). Customer satisfaction and word of mouth, Journal of Service Research, 1(1), 5-17. http://dx.doi.org/10.1177/109467059800100102

Arantola, H. (2002). Consumer bonding - A conceptual exploration. Journal of Relationship Marketing, 1(1), 93-107. http://dx.doi.org/10.1300/J366v01n02_06

Arham, M. (2010). Islamic perspectives on marketing. Journal of Islamic Marketing, 1(2), 149-164. http://dx.doi.org/10.1108/17590831011055888

Aurier, P., \& N'Goala, G. (2010). The differing and mediating roles of trust and relationship commitment in service relationship maintenance and development. Journal of the Academy of Marketing Science, Vol. 38, 303-325. http://dx.doi.org/10.1007/ s11747-009-0163-z

Bank Negara Malaysia. (2010). Takaful Annual Report 2010. Kuala Lumpur: Bank Negara Malaysia.

Bansal, H. S., P. G. Irving, \& S. F. Taylor. (2004). A three-component model of customer commitment to service providers. Journal of the Academy of Marketing Science, 32(3), 234-50.

Beekun, R. (2003). Islamic business ethics. New Delhi: Goodword Books.

Bejou, D., Ennew, C. T., \& Palmer, A. (1998). Trust, ethics, and relationship satisfaction. International Journal of Bank Marketing, 170-175. http://dx.doi. org/10.1108/02652329810220729 
Beloucif, A., Donaldson, B., \& Kazanci, U. (2004). Insurance broker-client relationships: An assessment of quality and duration. Journal of Financial Services Marketing , 8(4), 327-342. http://dx.doi.org/10.1057/palgrave.fsm.4770130

Berry, L. (1995). Relationship marketing orservices-growing interest, emerging perspectives. Journal of the Academy of Marketing Sciences, 23(4), 236-245. http://dx.doi.org/10.1177/009207039502300402

Berry, L. (2002). Relationship marketing of services-perspectives from 1983-2000. Journal of Relationship Marketing, 1(1), 59-77. http://dx.doi.org/10.1300/J366v01n01_05

Berry, L. L., \& Parasuraman, A. (1991). Marketing services. New York: The Free Press.

Boles, James, Thomas Brashear, Danny Bellenger, \& Hiram Barksdale, Jr. (2000). Relationship Selling Behaviors: Antecedents and Relationship with Performance. Journal of Business \& Industrial Marketing, 15(2-3), 141-153.

Boone, L., \& Kurtz, D. (2004). Contemporary marketing (7th ed.). New York: The Dyrden Press.

Brown, T. J., Barry, T. E., Dacin, P. A., \& Gunst, R. F. (2005), Spreading the word: Investigating antecedents of consumers' positive word-of-mouth intentions and behaviors in a retailing context, Journal of the Academy of Marketing Science, 33(2), 123-138. http://dx.doi.org/10.1177/0092070304268417

Bugel, M. S., Buunk, A. P., \& Verhoef, P. C. (2010). A comparison of customer commitment in five sectors using the psychological investment model. Journal of Relationship Marketing, 9, 2-29. http://dx.doi.org/10.1080/15332660903551883

Cannon, J. P., \& Perreault, W. D. (1999). Buyer-seller relationships in business markets. Journal of Marketing Research, 36(4), 439-460. http://dx.doi. org/10.2307/3151999

Castillo, J. J. (2009). Research Population. Retrieved June 7, 2012 from ExperimentResource.Com: http://www.experiment-resources.com/research-population.html

Chih, W. H., Huang, L. C., Yang, T. J., \& Cho, H. P. (2009). Online Relational Bond, Trust and Customer Loyalty. International Conference on Information Management and Engineering. http://dx.doi.org/10.1109/icime.2009.136

Chiu, H.-C., Lee, M., Hsieh, Y.-C., \& Chen, L.-Y. (2007). Building customer relationships: A comparison across multiple service encounters. Advances in Consumer Research, 34, 720-725.

Chopra, V. (2009). Marketing strategy for the 21st century. Journal of Marketing \& Communication, 5(1), 89-91.

Christy, R., Oliver, G., \& Penn, J. (1996). Relationship marketing in consumer markets. Journal of Marketing Management, 12(1-3), 175-187. http://dx.doi.org/10.1080 /0267257X.1996.9964407

Crosby, L. A., Evans, K. R., \& Cowles, D. (1990). Relationship quality in services selling: An interpersonal influence perspective. Journal of Marketing, 68-81. http://dx.doi.org/10.2307/1251817

De Wulf, K., Odekerken-Schroder, G., \& Iacobucci, D. (2001). Investment in consumer relationships: a cross-country and cross-industry exploration. Journal of Marketing, 65(4), 33-50. http://dx.doi.org/10.1509/jmkg.65.4.33.18386 
Dibb, S., \& Meadows, M. (2001). The Application of a Relationship Marketing Perspective in Retail Banking. The Service Industries Journal, 21(1), 169-194. http://dx.doi. org/10.1080/714005011

Dholakia, P. M., \& Morwitz, V. G. (2002). How surveys influence customers. Harvard Business Review, 80(5), 18-19.

Doney, P. M., \& Cannon, J. P. (1997). An examination of the nature of trust in buyerseller relationships. Journal of Marketing, 61(2), 35-51. http://dx.doi. org/10.2307/1251829

Dwyer, F., Schurr, P., \& Oh, S. (1987). Developing buyer-seller relationship. Journal of Marketing, 51, 11-27. http://dx.doi.org/10.2307/1251126

Eiriz, V., \& Wilson, D. (2006). Reserach in relationship marketing: antecedents, traditions and integration. European Journal of Marketing, 40(3/4), 275-291. http://dx.doi. org/10.1108/03090560610648057

Emmons, R. A. (2004). The psychology of gratitude: An introduction. In Robert A. Emmons, \& Michael E. MCollough (Eds.), The psychology of gratitude (pp. 3-16) New York: Oxford University Press.

Emmons, R. A., \& McCullough, M. E. (2003). Counting blessings versus burdens: An experimental investigation of gratitude and subjective well-being in daily life. Journal of Personality and Social Psychology, 84, 377-389. http://dx.doi. org/10.1037/0022-3514.84.2.377

Ennew, C., Kharouf, H., \& Sekhon, H. (2011). Trust in UK financial services: A longitudinal analysis. Journal of Financial Services Marketing, 65-75. http://dx.doi.org/10.1057/fsm.2011.8

Ernst \& Young. (2010). The World Takaful Report. Dubai: Mega Brands.

Ernst \& Young. (2013). Global Takaful Insight 2013, United Kingdom.

Ernst \& Young. (2014). Global Takaful Insight 2014, United Kingdom.

Ernst \& Young and MTA (2015). Malaysian Takaful Dynamics: Central Compendium 2015, Kuala Lumpur.

Fullerton, G. (2005). How commitment both enables and undermines marketing relationships. European Journal of Marketing, 39(11/12), 1372-1388. http://dx.doi.org/10.1108/03090560510623307

Fu, F. Q., Richards, K. A., Hughes, D. E., \& Jones, E. (2010). Motivating salesperson to sell new products: the relative influence of attitudes, subjective norms, and selfefficacy. Journal of Marketing, 74(November), 61-76. http://dx.doi.org/10.1509/ jmkg.74.6.61

Geyskens, I., Jan-Benedict Steenkamp, Lisa K. Scheer, \& Nirmalya Kumar. (1996). The effects of trust and interdependence on relationship commitment: A trans-atlantic study, International Journal of Research in Marketing, 13(4), 303-317.

Gronroos, C. (2004). The relationship marketing process: Commucation, interaction, dialogue, value. Journal of Business \& Industrial Marketing, 19(2), 99-113. http://dx.doi.org/10.1108/08858620410523981

Gummeson, E. (1994). Making relationship marketing operational. International Journal of Service Industry Management, 5(5), 5-20. http://dx.doi.org/10.1108/ 09564239410074349 
Gundlach, G. T., Achrol, R. S., \& Mentzer, J. T. (1995). The structure of commitment in exchange. Journal of Marketing, 59(January), 78-92. http://dx.doi.org/ $10.2307 / 1252016$

Gustafsson, A., Johnson, M. D., \& Roos, I. (2005). The effects of customer satisfaction, relationship commitment dimensions, and triggers on customer retention. Journal of Marketing, 69, 210-218. http://dx.doi.org/10.1509/jmkg.2005.69.4.210

Gwinner, K. P., Gremler, D. P., \& Bitner, M. J. (1998). Relational benefits in services industries: the customer's perspective. Journal of Marketing, 26(2), 101-114. http://dx.doi.org/10.1177/0092070398262002

Hair, J. F., Black, W. C., Babin, B. J., \& Anderson, R. E. (2010). Multivariate data analysis. New Jersey: Pearson Education Inc.

Hair, J. F., Sarstedt, M., M.Ringle, C., \& Mena, J. A. (2012). An assessment of the use of partial least squares structural equation modeling in marketing research. Journal of the Academic Marketing Science, 40, 414-433. http://dx.doi.org/10.1007/ s11747-011-0261-6

Hansen, J. D., \& Riggle, R. J. (2009). Ethical salesperson behavior in sales relationships. Journal of Personal Selling \& Sales Management, 29(2), 151-166. http://dx.doi. org/10.2753/PSS0885-3134290204

Harpham, E. (2004). The psychology of gratitude. In R. Emmons, \& M. McCullough, (Eds.), Gratitude in the history of ideas (pp. 19-36). New York: Oxford University Press.

Hassan, A., Chachi, A., \& Salma, A. L. (2008). Islamic marketing ethics and its impact on customer satisfaction in the Islamic Banking industry. Journal of King Abdul Aziz, 27-46. http://dx.doi.org/10.4197/islec.21-1.2

Hasan, S. F., Lings, I., Neale, L., \& Mortimer, G. (2014). The role of customer gratitude in making relationship marketing. Journal of Retailing and Consumer Services, 21, 788-796. http://dx.doi.org/10.1016/j.jretconser.2014.06.007

Homans, G. (1961). Social behavior. New York: Harcout, Brace, \& World.

Hussnain, S. A. (2011). What is Islamic marketing? Global Journal of Management and Business Research, 11(11). Online ISSN: 2249-4588 \& Print ISSN: 0975-5853.

Hsieh,Y., Chiu, H., \& Chiang, M. (2005). Maintaining a committed online customer: A study cross search-experience-credence products. Journal of Retailing, 81(1), 75-82. http://dx.doi.org/10.1016/j.jretai.2005.01.006

Huang, M.-H. (2015). The influence of relationship marketing investments on customer gratitude in retailing. Journal of Business Research, 68(6), 1318-1323. http://dx.doi.org/10.1016/j.jbusres.2014.12.001

Huang, M.-H. (2008). The influence of selling behaviours on customer relationships in financial services. International Journal of Service Industry Management, 19(4), 458-473. http://dx.doi.org/10.1108/09564230810891905

Hutchinson, D., Wellington, W. J., Saad, M., \& Cox, P. (2011). Refining value-based differentitaion in business relationships: A study of the higher order relationship building blocks that influence behavioral intentions. Industrial Marketing Management, 40, 465-478. http://dx.doi.org/10.1016/j.indmarman.2010.08.010 
Islamic Banking and Takaful Department, Bank Negara Malaysia. (2012). 20 Years Experience of Malaysian Takaful Industry. Retrieved March Monday, 2012, from Malaysia International Islamic Finance Centre from http://www.mifc.com/ publication/p.9.10.pdf

Jamal, A., \& Naser, K. (2003). Factors influencing customer satisfaction in the retail banking sector in Pakistan. International Journal of Commerce and Management, 13(2), 29-53. http://dx.doi.org/10.1108/eb047465

Jones, T., Taylor, S. F., \& Bansal, H. S. (2008). Commitment to a friend, a service provider, or a service company-are they distinctions worth making? Journal of the Academy of Marketing Science, 36, 473-487. http://dx.doi.org/10.1007/s11747-008-0107-z

Kamsol, M. K., Anuar, B., Norizah, K., Nik Ramli, N. A., \& Kamaruzaman, J. (2009). Retaining customers through relationship marketing in an Islamic financial instution in Malaysia. International Journal of Marketing Studies, 1(1), 66-71.

Kartajaya, H., \& Sula, M. S. (2006). Shariah marketing. Bandung Indonesia: Penerbit Mizan.

Kumar, N., Scheer, L., \& Steenkamp, E. (1995). The effects of perceived interdepence on dealer attitudes. Journal of Marketing Research, 32(August), 348-356. http://dx.doi.org/10.2307/3151986

Levine, J. H. (1996, June 10). Introduction to Data Analysis: Rules of Evidence. Retrieved from http://www.dartmouth.edu/ mss/data\%20analysis/002\%20table $\% 20$ of $\% 20$ contents.html

Liang, C.-J., \& Chen, H.-J. (2009). How to lengthen, deepen, and broaden customerfirm relationships with online financial services. Journal of Financial Services Marketing, 14(3), 218-231. http://dx.doi.org/10.1057/fsm.2009.20

Liang, C. C. L., \& Wang, W. W. W. (2005). Integrative research into the financial services industry in Taiwan: relationship bonding tactics, relationship quality and behavioural loyalty. Journal of Financial Services Marketing, 10(1), 65-83. http://dx.doi.org/10.1057/palgrave.fsm.4770174

Lin, N. P., Weng, J. C. M., \& Hsieh, Y. C. (2003). Relational bonds and customer's trust and commitment - A study on the moderating effects of web site usage. The Service Industries Journal, 23(3), 103-124. http://dx.doi.org/10.1080/714005111

Liu, Y., Luo, Y., \& Liu, T. (2009). Governing buyer-supplier relationships through transactional and relational mechanisms: Evidence from China. Journal of Operations Management, 27, 294-309. http://dx.doi.org/10.1016/j.jom.2008. 09.004

Lowry, P. B., \& Gaskin, J. (2014). Partial least squares (PLS) structural equation modeling (SEM) for building and testing behavioral causal theory: when to choose it and how to use it. IEEE Transactions on Professional Communication, 57(2), 123146. http://dx.doi.org/10.1109/TPC.2014.2312452

Maznah, W. O., \& Mohd Noor, M. A. (2010). Brand loyalty and relational marketing in Islamic banking system. Canadian Social Science, 6(1), 25-32.

McCullough, M. E., Emmons, R. A., \& Tsang, J. (2002). The grateful disposition: A conceptual and empirical topography, Journal of Personality and Social Psychology, 82, 112-127. http://dx.doi.org/10.1037/0022-3514.82.1.112 
Menon, K., \& O'Connor, A. (2007). Building customers' affective commitment towards retail banks: The role of CRM in each 'moment of truth'. Journal of Financial Services Marketing, 12(2), 157-168. http://dx.doi.org/10.1057/palgrave.fsm. 4760068

Meyer, J. P., \& Allen, N. J. (1991). A three-component conceptualization of organizational commitment. Human Resource Management Review, 1(1), 61-89. http://dx.doi. org/10.1016/1053-4822(91)90011-Z

Mohamed, O. E., Syed Othman, A., \& Kamaruddin, S. (2013). Factors influencing the penetration rate of Malaysian Takaful industry from Takaful managers' perspective. 4th International Conference on Business and Economics Research, (pp. 353-366). Bandung.

Mohamad Shafique, A. R. (2013). Essentials elements in marketing and carrying out promotional activities for Islamic banking products. The 2nd International Conference on Islmaic Economics and Economies of the OIC Countries (ICIE 2013), (pp. 1-24). Kuala Lumpur.

Mohd Irwan, S. A. (2013). The role of Islamic finance in the growth of Malaysia. 4th Annual the World Takaful Conference-keynote speaker. MEGA: Islamic Finance Conference.

Moorman, C., Zaltman, G., \& Deshpande, R. (1992). Relationships between providers and users of marketing research: The dynamics of trust within and between organizations. Journal of Marketing Research, 29(August), 314-329. http:// dx.doi.org/10.2307/3172742

Moorman, C., R. Deshpande, and G. Zaltman. (1993). Factors affecting trust in market research relationships, Journal of Marketing, 57(1), 81-101. http://dx.doi. org/10.2307/1252059

Morgan, R. M., \& Hunt, S. D. (1994). The commitment-trust theory of relationship marketing. Journal of Marketing, 58, 20-38. http://dx.doi.org/10.2307/1252308

Murphy, P. E., Lazniak, G. R., \& Wood, G. (2007). An ethical basis for relationship marketing: A virtue ethics perspective. European Journal of Marketing, 37-57. http://dx.doi.org/10.1108/03090560710718102

Nafik HR, Muhammad, and Ratnasari, Ririn Tri. (2012). Measuring Islamic Compliance on The Moderating Effects of Islamic knowledge Level and The Relationship Between Trust and Loyalty Intention. International Conference on Business and Management 6-7 September 2012, Phuket - Thailand

Nath, V., Gugnani, R., Goswami, S., \& Gupta, N. (2009). An insight into customer relationship management practices in selected indian service industries. Journal of Marketing and Communication, 4(3), 18-40.

Nath, P., \& Mukherjee, A. (2012). Complementary effects of relational bonds in information asymmetry contexts. Journal of Services Marketing, 26(3), 168-180. http://dx.doi.org/10.1108/08876041211223979

Nazlida, M., \& Mizerski, D. (2010). The constructs mediating religions' influence on buyers and consumers. Journal of Islamic Marketing, 1(2), 124-135. http://dx.doi.org/10.1108/17590831011055860 
Ndubisi, N. O. (2006). A structural equation modelling of the antecedents of relationship quality in the Malaysia banking sector. Journal of Financial Services Marketing, 11(2), 131-141. http://dx.doi.org/10.1057/palgrave.fsm.4760033

Ndubisi, N. O., \& Wah, C. K. (2005). Factorial and discriminant analyses of the underpinnings of relationship marketing and customer satisfaction. International Journal of Bank Marketing, 23(7), 542-557. http://dx.doi.org/ $10.1108 / 02652320510629908$

Oliver, R. (1980). A cognitive model of the antecedents and consequences of satisfaction decisions. Journal of Marketing Research, November, 460-469. http://dx.doi. org/10.2307/3150499

Oliver, R. L. (1981). Measurement and evaluation of satisfaction process in retail settings. Journal of Retailing, 57(3), 25-48.

Oliver, R. L. (1999). Whence consumer loyalty. Journal of Marketing, 63, 33-44. http://dx.doi.org/10.2307/1252099

Olsen, S. O. (2002). Comparative evaluation and the relationship between quality, satisfaction, and repurchase loyalty. Journal of the Academy of Marketing Science, 30(3), 240-249. http://dx.doi.org/10.1177/0092070302303005

Palmatier, R. W., Rajiv, P. D., Druv, G., \& Kenneth, R. E. (2006). Factors influencing the effectiveness of relationship marketing: A meta-analysis. Journal of Marketing, 70(October), 136-153. http://dx.doi.org/10.1509/jmkg.70.4.136

Palmatier, R. W. (2008). Relationship marketing. Cambridge: MArketing Science Institute.

Palmatier, R. W., Jarvis, C. B., Bechkoff, J. R., \& Kardes, F. R. (2009). The role of customer gratitude in relationship marketing. Journal of Marketing, 73, 1-18. http://dx.doi. org/10.1509/jmkg.73.5.1

Peng, L. Y., \& Wang, Q. (2006). Impact of relationship marketing tactics (RMT) on switchers and stayers in a competitive service industry. Journal of Marketing Management, 22, 25-59. http://dx.doi.org/10.1362/026725706776022263

Peterson, R. A. (1995). Relationship marketing and the consumer. Journal of the Academy of Marketing Science, 23(4), 278-281. http://dx.doi.org/10.1177/ 009207039502300407

Piercy, N. F., \& Lane, N. (2007). Ethical and moral dilemmas associated with strategic relationships between business-to-business buyers and sellers. Journal of Business Ethics, 72, 87-102. http://dx.doi.org/10.1007/s10551-006-9158-6

Powers, T. L., \& Reagan, W. R. (2007). Factors influencing successful buyer-seller relationships. Journal of Business Research, 60, 1234-1242. http://dx.doi. org/10.1016/j.jbusres.2007.04.008

Reichheld, F. F. (1996). The loyalty effect: The hidden force behind growth, profits and lasting value. Boston: Harvard Business School Press.

Reichheld, F. F., \& Kenny, D. W. (1990). The hidden advantages of customer retention. Journal of Retail Banking, 12(4), 19-23.

Reynolds, K. E., \& Beatty, S. E. (1999). Customer benefits and company consequences of customer-salesperson relationships in retailing. Journal of Retailing, 75(1): 11-32. http://dx.doi.org/10.1016/S0022-4359(99)80002-5 
Rice, G. (1999). Islamic ethics and the implications for business. Journal of Business Ethics, 18(4), 345-358. http://dx.doi.org/10.1023/A:1005711414306

Rizk, R. R. (2008). Back to basic: An Islamic perspective on business and work ethics. Social Responsibility Journal, 4(1/2), 246-254. http://dx.doi.org/10.1108/ 17471110810856992

Roberts, K., Varki, S., \& Brodie, R. (2003). Measuring the quality of relationships in consumer services: An empirical study. European Journal of Marketing, 37(1/2), 169-196. http://dx.doi.org/10.1108/03090560310454037

Rodriquez, C., \& Wilson, D. (1999). Relationship bonding and trust as foundation for commitment in International Strategi Alliances, USA-Mexico: A latent variable strucral modeling approach. Philadelphia: ISM Report 21: Institute for the Study of Business Markets.

Roman, S. (2003). The impact of ethical sales behaviour on customer satisfaction, trust, and loyalty to the company: An empirical study in the financial services industry. Journal of Marketing Management, 19(9-10), 915-939. http://dx.doi.org/10.108 0/0267257X.2003.9728245

Roman, S., \& Ruiz, S. (2005). Relationship outcomes of perceived ethical sales behaviour: the customer's perspective. Journal of Business Research, 58(4), 439-445. http://dx.doi.org/10.1016/j.jbusres.2003.07.002

Rotter, J. B. (1967). A new scale for the measurement of interpersonal trust. Journal of Personality, 35(4), 651-665. http://dx.doi.org/10.1111/j.1467-6494.1967. tb01454.x

Rust, R. T., \& Oliver, R. L. (1994). Service quality: New directions in theory and practice. London: SAGE.

Schurr, P. H., \& Ozanne, J. L. (1985). Influences on exchange processes: Buyers' preconceptions of a seller's trustworthiness and bargaining toughness. Journal of Consumer Research, 11(4), 939-953. http://dx.doi.org/10.1086/209028

Shammout, A. B., Zeidan, S., \& Polonsky, M. J. (2006). Exploring the links between relational bonds and customer loyalty: The case of loyal Arabic guest at five start hotels. Conference proceedings of the Australian and New Zealand Marketing Academy Conference. Brisbance, Australia: Queensland University of Technology.

Shamsudin, A. S., Kassim, A. W., Hassan, M. G., \& Johari, N. A. (2010). Preliminary insights on the effect of Islamic work ethics on relationship marketing and customer satisfaction. The Journal of Human Resource and Adult Learning, 6(1), $106-114$.

Sharma, N., Young, L., \& Wilkinson, I. (2006). The commitment mix: Dimensions of commitment in international trading relationships in India. Journal of International Marketing, 14(3), 64-91. http://dx.doi.org/10.1509/jimk.14.3.64

Sin, L. Y., Tse, A. C., Yau, O. H., Lee, J. S., \& Chow, R. (2002). The effect of relationship marketing orientation on business performance in a serviceoriented economy. Journal of Service Marketing, 16(7), 656-676. http://dx.doi. org/10.1108/08876040210447360

Sirdeshmukh, D., Singh, J., \& Sabol, B. (2002). Consumer trust, value, and loyalty in relational exchanges. Journal of Marketing, 66, 13-37. http://dx.doi.org/10.1509/ jmkg.66.1.15.18449 
Smith, J. B. (1998), Buyer-seller relationships: Similarity, relationship management, and quality. Psychol. Mark. http://dx.doi.org/10.1002/(SICI)1520-6793(199801) $15: 1<3::$ AID-MAR2 $>3.0$. CO;2-I

Swan, J. E., \& Nolan, J. J. (1985). Gaining customer trust: A conceptual guide for the salesperson. Journal of Personal Selling and Sales Management, 39-48.

Swan, J. E., \& Trawick, J. I. (1987). Building customer trust in the industrial salesperosn: process and outcomes. Advance in Business Marketing, 2, 81-113.

Swan, J. E., Trawick, I. F., Jr., Rink, D. R., \& Robert, J. J. (1988). Measuring dimensions of purchaser trust of industrial sales people. Journal of Personal Selling \& Sales Management, Vol VIII, 1-9.

Szymanski, D. M., \& Henard, D. H. (2001). Customer satisfaction: A meta-analysis of the empirical evidence, Journal of the Academy of Marketing Science, 29(1), 16-35. http://dx.doi.org/10.1177/0092070301291002

Takala, T., \& Uusitalo, O. (1996). An alternative view of relationship marketing: A framework for ethical analysis. European Journal of Marketing, 30(2), 45-60. http://dx.doi.org/10.1108/03090569610106644

Tam, J. L. M., \& Wong, Y. H. (2001), Interactive selling: A dynamic framework for services. Journal of Services Marketing, 15(5), 379-396.

Thibaut, J., \& Kelley, H. (1959). The social psychology of groups. New York: Wiley.

Turnbull, P. W., \& Wilson, D. T. (1989). Developing and protecting profitable customer relationships. Industrial Marketing Management, 18, 233-238. http://dx.doi. org/10.1016/0019-8501(89)90040-0

Williams, J. D., Han, S. L., \& Qualls, W. J. (1998). A conceptual model and study of crosscultural business relationships. Journal of Business Research, 42(2), 135-143. http://dx.doi.org/10.1016/S0148-2963(97)00109-4

Wilson, D. T. (1995). An integrated model of buyer-seller relationship. Journal of the Academy of Marketing Science, 23(4), 335-345. http://dx.doi.org/ $10.1177 / 009207039502300414$

Wilson, D. T., \& Jantrania, S. A. (1993). Understanding the value of a relationship. International Colloquium Relationship Marketing. Melbourne: Monash University.

Wilson, J. A. (2012). The new wave of transformational Islamic marketing. Journal of Islamic Marketing, 3(1), 5-11. http://dx.doi.org/10.1108/17590831211225436

Wong, K. K. (2013). Partial Least Squares Structural Equation Modeling (PLS-SEM) Techniques. Marketing Bulletin, 24(1), 1-32.

Wotruba, T. R. (1990). A comprehensive framework for the analysis of ethical behaviour, with a fcus on sales organizations. Journal of Personal Selling \& Sales Management, $x$ (spring), 29-42.

Wu, J. \& Liu, D. (2007). The Effects of Trust and Enjoyment on Intention to Play Online Games. Journal of Electronic Commerce Research, 8(2), 128-140.

Young, E. a. (2014). Global Takaful Insights 2014. Ernst and Young.

Yusuf, J. B. (2010). Ethical implications of sales promotion in Ghana: Islamic perspective. Journal of Islamic Marketing, 1(3), 220-230. http://dx.doi. org/10.1108/17590831011082400 